\title{
Preparation of Metaettringite from Ettringite and Its Performance for Boron Removal from Boric Acid Solution
}

\author{
Atsushi Iizuka ${ }^{1, *}$, Miyuki Takahashi ${ }^{1}$, Takashi Nakamura $^{1}$ and Akihiro Yamasaki ${ }^{2}$ \\ ${ }^{1}$ Research Center for Sustainable Science and Engineering, Institute of Multidisciplinary Research for Advanced Materials, Tohoku \\ University, Sendai 980-8577, Japan \\ ${ }^{2}$ Department of Materials and Life Science, Faculty of Science and Technology, Seikei University, Tokyo 180-8633, Japan
}

\begin{abstract}
Metaettringite was prepared by heat treatment of ettringite, and its boron removal performance from solutions at low concentrations $(25 \mathrm{mg} / \mathrm{L}$ boron $(\mathrm{mg}-\mathrm{B} / \mathrm{L}))$ was investigated. With a calcination temperature of $>65^{\circ} \mathrm{C}$, amorphous metaettringite formed, and this showed better boron removal performance than ettringite. The dominant mechanism for boron removal by metaettringite was incorporation of $\mathrm{B}(\mathrm{OH})_{4}{ }^{-}$in the ettringite structure during its regeneration from metaettringite by hydration. The highest uptake was $15.1 \mathrm{mg}$ of boron per gram of metaettringite. Boron in solution could be effectively removed by metaettringite over a wide initial $\mathrm{pH}$ range of 5.22 to 11 . Residual boron concentrations were lower than those specified by the Japanese effluent standard (10 mg-B/L) even when using metaettringite with a large particle size. Boron removal was strongly suppressed by high temperatures, but a residual boron concentration lower than 10 mg-B/L was obtained when the mass concentration of adsorbent in the boron solution was increased. [doi:10.2320/matertrans.M-M2017839]
\end{abstract}

(Received April 13, 2017; Accepted September 27, 2017; Published November 17, 2017)

Keywords: $\quad$ wastewater treatment, ettringite, metaettringite, boron, ion exchange, rehydration

\section{Introduction}

Boron is an essential micronutrient in living organisms, but excess boron can cause toxic effects. Currently, boron compounds are important materials in many industries, and discharge of this boron into the environment must be controlled to avoid adverse effects on aquatic organisms. Consequently, boron removal from water has received much attention. Recent reviews ${ }^{1-3)}$ have detailed the various physicochemical methods that have been investigated to remove boron from wastewater, including coagulation, sedimentation, adsorption, chelation and ion exchange resins, and membrane separation. Among the boron separation processes, removal with solid sorbents ${ }^{4-7)}$ is advantageous over other methods in terms of the overall simplicity of the process. However, most sorbents are too expensive for largescale effluent treatment. Therefore, inexpensive materials for boron removal need to be developed to reduce the overall cost of treatment of wastewater containing boron.

Metaettringite is the thermal dehydration product of ettringite $\left(\mathrm{Ca}_{6} \mathrm{Al}_{2}\left(\mathrm{SO}_{4}\right)_{3}(\mathrm{OH})_{12} \cdot 25-26 \mathrm{H}_{2} \mathrm{O}\right)$. It is well known that ettringite can participate in anion exchange where its $\mathrm{SO}_{4}{ }^{2-}$ ions are exchanged for other anions such as $\mathrm{B}(\mathrm{OH})_{4}{ }^{-}$, $\mathrm{CrO}_{4}{ }^{2-}, \mathrm{SeO}_{3}{ }^{2-}$, ${ }^{8-11)}$ or $\mathrm{F}^{-}{ }^{12)}$ However, the uptake rates of anions in this process are generally low. In a preliminary study ${ }^{13)}$, we confirmed that thermal treatment of ettringite to generate metaettringite resulted in enhancement of the boron uptake rate. The elements in ettringite are ubiquitous, and it can be easily synthesized by mixing calcium hydroxide $\left[\mathrm{Ca}(\mathrm{OH})_{2}\right]$ and aluminum sulfate $\left[\mathrm{Al}_{2}\left(\mathrm{SO}_{4}\right)_{3}\right]$ in solution. Metaettringite can be obtained by heating ettringite at a relatively low temperature. Thus, it would be of great industrial significance if metaettringite could be used for boron removal.

Here, we describe the preparation of metaettringite powder and its performance for the removal of boron from solu-

*Corresponding author, E-mail: atsushi.iizuka.e4@tohoku.ac.jp tion at a low concentration $(25 \mathrm{mg} / \mathrm{L}$ boron $(\mathrm{mg}-\mathrm{B} / \mathrm{L}))$.

\section{Experimental}

\subsection{Preparation of ettringite and metaettringite}

Ettringite powder was synthesized as follows. A saturated solution of calcium sulfate was prepared by mixing $\mathrm{CaSO}_{4} \cdot 2 \mathrm{H}_{2} \mathrm{O}$ (purity $98 \%$, Wako Pure Chemical Industries, Osaka, Japan) and distilled water. The saturated solution $(100 \mathrm{~mL})$ was filtered through a syringe filter (pore size: $0.45 \mu \mathrm{m}$ ) and heated to $80^{\circ} \mathrm{C}$ in a plastic beaker (volume: $500 \mathrm{~mL})$ in a water bath. $\mathrm{Ca}(\mathrm{OH})_{2}(0.06 \mathrm{~mol}$, purity $96.0 \%$, Wako Pure Chemical Industries) and $\mathrm{Al}_{2}\left(\mathrm{SO}_{4}\right)_{3}(0.01 \mathrm{~mol}$, $85.0 \%$, Wako Pure Chemical Industries) were each dissolved in $100 \mathrm{~mL}$ of distilled water. The main impurity in $\mathrm{Al}_{2}\left(\mathrm{SO}_{4}\right)_{3}$ was water, and the amount of impurities was taken into account when preparing the solution. The $\mathrm{Ca}(\mathrm{OH})_{2}$ solution $(100 \mathrm{~mL})$ and $\mathrm{Al}_{2}\left(\mathrm{SO}_{4}\right)_{3}$ solution $(100 \mathrm{~mL})$ were poured into a beaker with the $100 \mathrm{~mL}$ of $\mathrm{CaSO}_{4} \cdot 2 \mathrm{H}_{2} \mathrm{O}$ solution, and then the total volume was adjusted to $500 \mathrm{~mL}$ with distilled water. The mixture was then stirred for $4 \mathrm{~h}$ at $80^{\circ} \mathrm{C}$. The ettringite slurry generated was filtered by pressure filtration through a membrane (pore size: $3 \mu \mathrm{m}$ ), and washed thoroughly with distilled water. Finally, the solids were dried in a freeze dryer overnight, and then crushed with a muddler. The drying and crushing procedures were repeated to obtain dry samples. Generation of the ettringite phase was determined by X-ray diffraction (XRD; RINT2000, Rigaku, Tokyo, Japan). For the XRD measurements, the voltage and current for X-ray generation were $40 \mathrm{kV}$ and $30 \mathrm{~mA}$, respectively. The $2 \theta$ range was $5^{\circ}-60^{\circ}$, the step size was $0.02^{\circ}$, and the scan speed was $1.5^{\circ} / \mathrm{min}$. The dehydration of ettringite to metaettringite was investigated by thermogravimetric analysis (Thermo plus Evo, Rigaku). Thermogravimetric analysis was conducted from room temperature to $1000^{\circ} \mathrm{C}$, with a heating rate of $10^{\circ} \mathrm{C} / \mathrm{min}$, and under an argon atmosphere.

Metaettringite was then prepared by calcination of ettring- 
ite at different temperatures for $72 \mathrm{~h}$. The particle sizes of the ettringite and metaettringite samples were adjusted by sieving. Observation of the surfaces of the obtained samples was carried out with a scanning electron microscope (SEM; VE-9800, Keyence, Osaka, Japan).

The prepared ettringite and metaettringite samples were dissolved in acid, and the concentrations of $\mathrm{Ca}, \mathrm{Al}$, and $\mathrm{S}$ were determined by inductively coupled plasma atomic emission spectrometry (Spectro Arcos, Ametek Co. Ltd., Tokyo, Japan).

\subsection{Boron removal experiments}

An aqueous solution of boric acid was prepared from reagent-grade boric acid (purity 99.5\%, Wako Pure Chemical Industries) and distilled water. The $\mathrm{pH}$ of the solution was adjusted by adding an aqueous sodium hydroxide $(\mathrm{NaOH})$ solution. The prepared ettringite or metaettringite was added to the boron solution $(500 \mathrm{~mL})$ in a TPX beaker (methylpentene polymer, volume $=500 \mathrm{~mL}$ ), and the solution was stirred with a magnetic stirrer at $400 \mathrm{rpm}$. The initial boron concentration in the solution was set at $25 \mathrm{mg}-\mathrm{B} / \mathrm{L}$ to reflect the boron concentrations typically found in mine wastewater in Japan. This value is higher than the Japanese effluent standard of $10 \mathrm{mg}-\mathrm{B} / \mathrm{L}$ (Water Quality Pollution Control Act of Japan, 2011). The boron removal experiments were continued for up to $2 \mathrm{~h}$. To evaluate the performance of metaettringite for boron removal, the apparent sorption isotherm was measured. In this case, the initial boron concentration was varied between 10 and $1000 \mathrm{mg}-\mathrm{B} / \mathrm{L}$. The solution temperature was set to 10,23 , or $50^{\circ} \mathrm{C}$. The solution temperature was regulated by controlling the atmospheric temperature for the 10 and $23^{\circ} \mathrm{C}$ experiments, and with a water bath for the $50^{\circ} \mathrm{C}$ and $70^{\circ} \mathrm{C}$ experiments. The mass of metaettringite or ettringite adsorbent added to the boron solution was varied between 5 and $10 \mathrm{~g}$ (mass concentration of adsorbent $10-20 \mathrm{~g} / \mathrm{L}$ ). Metaettringite and ettringite with different particle diameter distributions (53-106, 106-212, and $250-500 \mu \mathrm{m}$ ) were used. The initial $\mathrm{pH}$ of the solution was varied in the range $5.22-11$. The $\mathrm{pH}$ was periodically measured with a pH meter (AUT-701, TOA DKK, Tokyo, Japan). The solutions were periodically sampled through a $0.45 \mu \mathrm{m}$ cellulose filter, and the concentrations of $\mathrm{B}, \mathrm{Ca}, \mathrm{Al}$, and $\mathrm{S}$ in the samples were determined by inductively coupled plasma atomic emission spectrometry (Spectro Arcos, Ametek Co. Ltd.). After each boron removal experiment, the solid was recovered from the solution by filtration through filter paper, and the retained solid was dried under atmospheric conditions for $24 \mathrm{~h}$. The dried samples were analyzed by XRD. A solid-state high-resolution nuclear magnetic resonance spectrometer (Avance 600, Bruker Biospin K.K., Yokohama, Japan) was used to determine the coordination number of boron in the ettringite.

\section{Results and Discussion}

\subsection{Preparation of ettringite and metaettringite}

Figure 1 shows XRD patterns of the synthesized ettringite and metaettringite samples calcined at different temperatures. The XRD pattern of the ettringite sample confirmed that it was highly crystalline and single-phase ettringite
(ICDD entry 075-7554, largest peak position $9.09^{\circ}$ ). The $\mathrm{XRD}$ patterns of the samples calcined at $<60^{\circ} \mathrm{C}$ showed the same pattern as non-treated ettringite. However, for samples heat-treated at $\geq 65^{\circ} \mathrm{C}$, the ettringite peaks were not present. This indicates that amorphous metaettringite was formed at $\geq 65^{\circ} \mathrm{C}$. The behavior of ettringite on heating agreed with that observed in earlier reports ${ }^{14-18)}$. The XRD pattern of the metaettringite sample prepared by thermal treatment of ettringite at $200^{\circ} \mathrm{C}$ (Fig. 1(f)) contained small peaks that could be assigned to bassanite $\left(\mathrm{CaSO}_{4} \cdot 0.5 \mathrm{H}_{2} \mathrm{O}\right)$ (ICDD entry 083-0439, largest peak position $14.74^{\circ}$ ).

Figure 2 shows the dehydration curve of ettringite as a function of temperature. In the figure, the initial number of water molecules per molar mass of ettringite was assumed to be 32 , according to the literature ${ }^{19)}$. Water molecules in the ettringite structure were rapidly removed at temperatures up to $100^{\circ} \mathrm{C}$, and then the number of water molecules per molar mass gradually decreased. The dehydration and rehydration of ettringite has been investigated previously. ${ }^{14-18)}$ Moore and Taylor $(1970)^{19)}$ classified the 32 water molecules in ettringite into the following four groups: (I) two water molecules in intercolumn channels; (II-a) 12 water molecules at

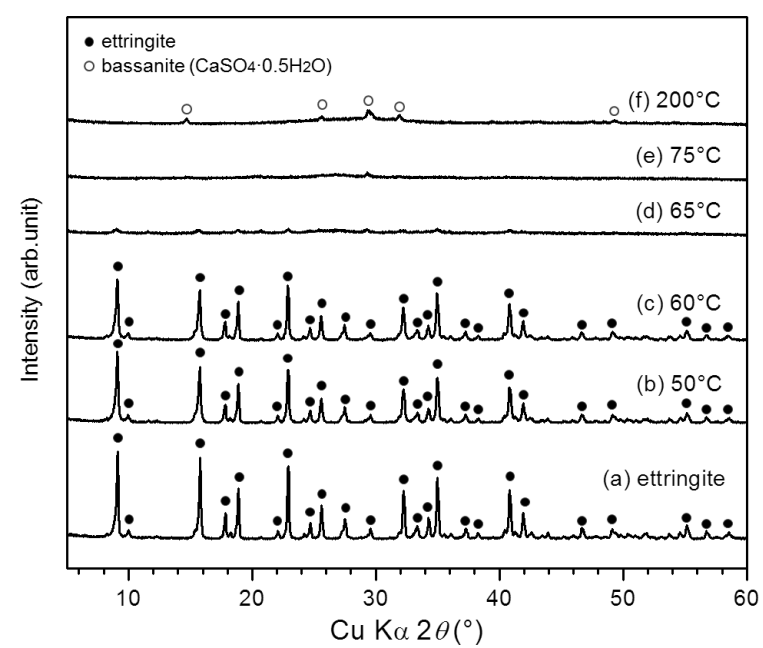

Fig. 1 XRD patterns of synthesized ettringite and ettringite samples calcined at different temperatures.

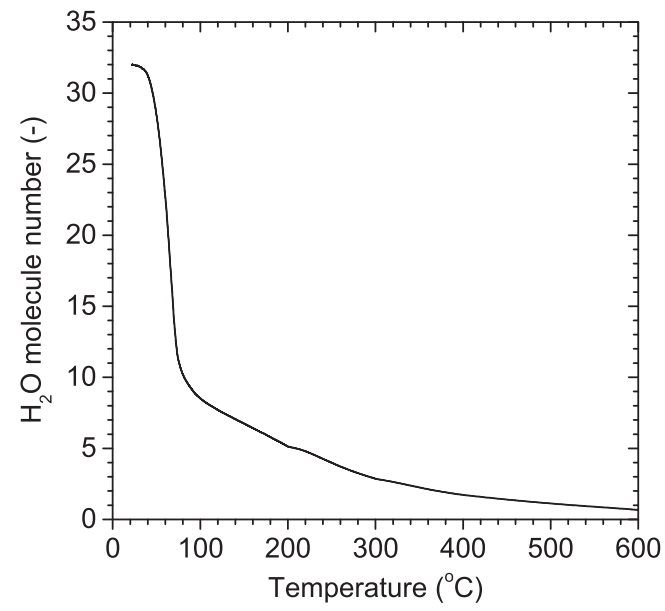

Fig. 2 Dehydration curve of ettringite as a function of temperature. 
the additional vertices of the trigonal prisms; (II-b) 12 water molecules at the main vertices of the trigonal prisms; and (III) six water molecules in hydroxyl form in the $\mathrm{Al}$ and $\mathrm{Ca}$ polyhedra of the columns. After calcination at $60^{\circ} \mathrm{C}$ and $65^{\circ} \mathrm{C}$, the numbers of water molecules remaining in the ettringite structure were estimated to be 22.7 and 18.5 per molar mass, respectively. It appeared that the water molecules in the first two groups (I and II-a) were thermally removed from the ettringite structure at $<65^{\circ} \mathrm{C}$, and this resulted in formation of amorphous metaettringite. However, inflection points were not observed in the thermogravimetric plots near $65^{\circ} \mathrm{C}$, although the XRD patterns showed drastic structural changes.

The water mass fractions in ettringite structures with 32 , 18 , and 6 water molecules were calculated at 45.9, 32.3, and $13.7 \%$, respectively. These figures show that dehydration of ettringite results in large mass decreases, and vice versa.

Table 1 shows the elemental compositions of the prepared ettringite and metaettringite (ettringite heated at $200^{\circ} \mathrm{C}$ ). The contents of calcium, aluminum, and sulfur in ettringite were lower than those in metaettringite, and this could be attributed to the removal of water molecules during heat treatment. From these values, the molar ratios of $\mathrm{Ca}: \mathrm{Al}: \mathrm{S}$ in the prepared materials were calculated to be 6.0:1.9:2.9 for ettringite and 6.0:1.9:3.0 for metaettringite. These values are in good agreement with the molar ratio of $6: 2: 3$ in the ettringite and metaettringite structure.

Figure 3 shows typical SEM images of ettringite and the thermally treated powders. Characteristic needle-shaped pri-

Table 1 Elemental compositions of the prepared ettringite and metaettringite (ettringite heated at $200^{\circ} \mathrm{C}$ ).

\begin{tabular}{llll}
\hline & \multicolumn{3}{l}{ Composition [mass\%] } \\
\cline { 2 - 4 } & $\mathrm{Ca}$ & $\mathrm{Al}$ & $\mathrm{S}$ \\
\hline Ettringite & 21.2 & 4.4 & 8.3 \\
Metaettringite & 33.3 & 7.1 & 13.2 \\
\hline
\end{tabular}

mary particles were observed for ettringite, and the ettringite powder contained secondary particles consisting of agglomerated needle-shaped ettringite crystals (Fig. 3(a)). The basic particle shape did not change after thermal treatment. The needle-shaped metaettringite was probably formed by heat treatment, as described in the literature. ${ }^{18)}$ However, it should be noted that the particle shapes of the samples can be affected by vacuum applied during the observation.

\subsection{Boron removal performance of ettringite and metaettringite}

\subsubsection{Influence of temperature during metaettringite preparation}

Figure 4 shows changes in the boron concentration with time after ettringite and metaettringite samples prepared at different temperatures were added to the boron solution. The observed boron removal performance of the samples agreed with their structures shown in the XRD patterns (Fig. 1). The ettringite samples thermally treated at $<60^{\circ} \mathrm{C}$ showed very low boron removal performance. However, the ettring-

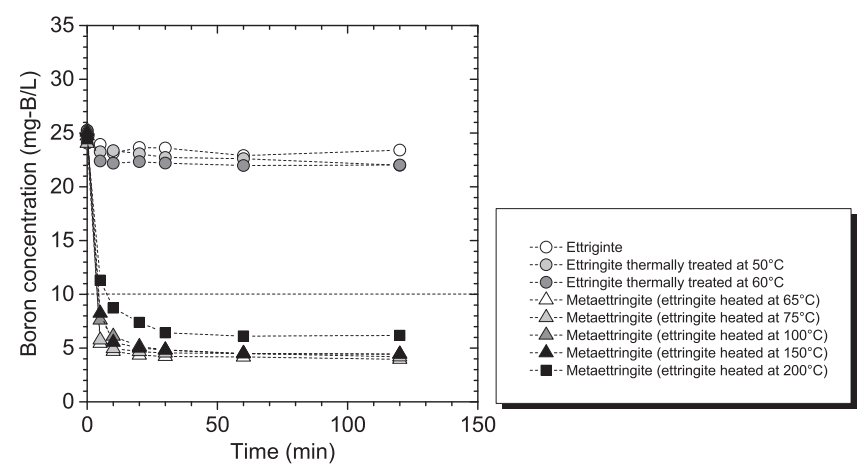

Fig. 4 Changes in the boron concentration with time after ettringite and metaettringite samples prepared at different temperatures were added to a boron solution. Initial boron concentration $25 \mathrm{mg}-\mathrm{B} / \mathrm{L}$, mass concentration of adsorbent $10 \mathrm{~g} / \mathrm{L}$, initial $\mathrm{pH} 5.22$, solution temperature $23^{\circ} \mathrm{C}$, and particle size $53-106 \mu \mathrm{m}$.
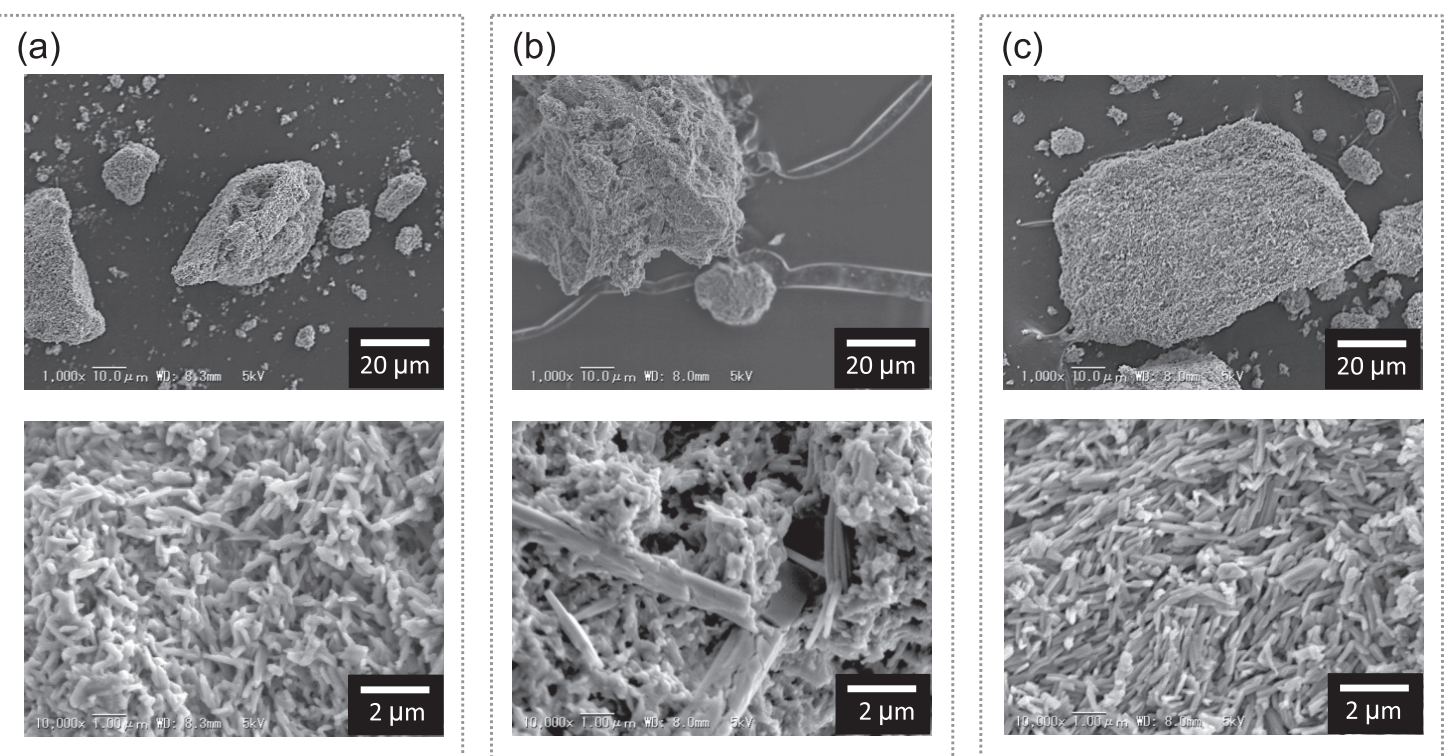

Fig. 3 SEM images of (a) ettringite and ettringite heat-treated at (b) $100^{\circ} \mathrm{C}$ for $30 \mathrm{~min}$ and (c) $200^{\circ} \mathrm{C}$ for $30 \mathrm{~min}$. 
ite samples thermally treated at $>65^{\circ} \mathrm{C}$ showed good boron removal performance, and the residual boron concentrations were lower than the Japanese effluent standard (uniform standard: $10 \mathrm{mg}-\mathrm{B} / \mathrm{L}$ ). It is reported that the ion exchange by metaettringite would occur in the intercolumn space inside the particle as well as the surface layer during recrystallization of metaettringite through hydration. Therefore, the borate adsorption amount of the metaettringite was much higher than the ettringite ${ }^{13)}$. To determine the repeatability, we measured changes in the boron concentration with time in repeated experiments, and found that the relative standard deviation for the final boron concentration was about $10 \%$.

With a preparation temperature of $>65^{\circ} \mathrm{C}$, the boron removal performance of the prepared metaettringite slightly decreased with increasing preparation temperature. This could be attributed to decomposition of metaettringite and generation of gypsum. After addition of solid samples to the boron solution, the solution $\mathrm{pH}$ immediately increased and then leveled off at $>10$ in all cases. This occurred because of dissolution of ettringite or metaettringite and the associated release of hydroxyl ions in the $\mathrm{Al}$ and $\mathrm{Ca}$ polyhedra of the columns. Increases in calcium, aluminum, and sulfur concentrations were also observed because of the dissolution of ettringite or metaettringite.

In subsequent experiments, metaettringite prepared from ettringite by heat treatment at $200^{\circ} \mathrm{C}$ was used as a representative sample of metaettringite because of its stability against rehydration during storage. Hereafter, metaettringite refers to the material formed by heat treatment of ettringite at $200^{\circ} \mathrm{C}$.

Figure 5 shows XRD patterns of ettringite and metaettringite before and after boron removal. No significant differences were observed in the XRD patterns of ettringite before and after boron removal. Regeneration of the ettringite structure was clearly observed for the metaettringite sample after boron removal. This was also observed for metaettringite prepared at other temperatures. Metaettringite did not enhance boron removal through an equilibrium shift but through a kinetic effect. This is because the ettringite structure was regenerated from the metaettringite structure after contact with water, and the crystallinity of the regenerated ettringite after boron uptake was lower than that of the original ettringite. This could be because of boron uptake during the rehydration process.

The coordination number of boron in both ettringite and metaettringite after boron removal was confirmed to be four from measurements using a solid-state high-resolution nuclear magnetic resonance spectrometer (data not shown). Therefore, boron exists in the form of $\mathrm{B}(\mathrm{OH})_{4}{ }^{-}$in the ettringite structure. Thus, the dominant mechanism for boron removal by metaettringite is considered to be incorporation of $\mathrm{B}(\mathrm{OH})_{4}{ }^{-}$in the ettringite structure during regeneration of the ettringite structure from metaettringite by hydration.

Table 2 shows the ratio of the amount of solid phase after boron removal to the initial feed amount for ettringite and the heat-treated ettringite samples. For ettringite, the amount of solid phase after boron removal decreased because of dissolution of ettringite into the boron solution. For the metaettringite samples, the amount of solid phase after boron

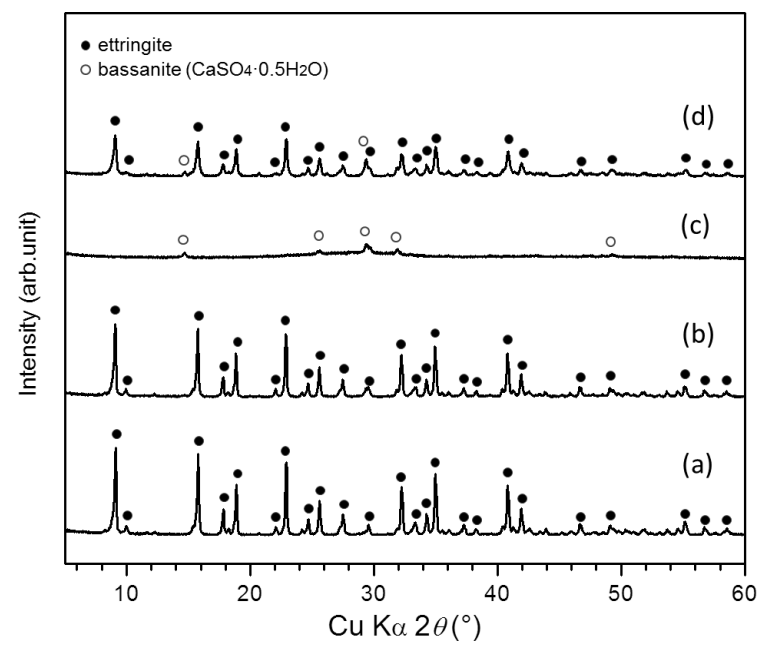

Fig. 5 XRD patterns of ettringite and metaettringite before and after boron removal. (a) Ettringite before boron removal, (b) ettringite after boron removal, (c) metaettringite before boron removal, and (d) metaettringite after boron removal.

Table 2 Ratio of the amount of solid phase after boron removal to initial feed amount.

\begin{tabular}{ll}
\hline Sample & $\begin{array}{l}\text { Ratio of solid phase } \\
\text { to initial feed (\%) }\end{array}$ \\
\hline Ettringite & 74 \\
Ettringite thermally treated at $50^{\circ} \mathrm{C}$ & 92 \\
Ettringite thermally treated at $60^{\circ} \mathrm{C}$ & 94 \\
Metaettringite (ettringite heated at $65^{\circ} \mathrm{C}$ ) & 114 \\
Metaettringite (ettringite heated at $75^{\circ} \mathrm{C}$ ) & 126 \\
Metaettringite (ettringite heated at $100^{\circ} \mathrm{C}$ ) & 137 \\
Metaettringite (ettringite heated at $150^{\circ} \mathrm{C}$ ) & 139 \\
Metaettringite (ettringite heated at $200^{\circ} \mathrm{C}$ ) & 138 \\
\hline
\end{tabular}

removal increased because of the rehydration of metaettringite to form the ettringite structure. It should be noted that the experimental solution was just a boric acid solution, and mass increases caused by boron uptake, which were calculated from the decrease in the boron concentration, did not completely account for the observed mass increase. Any water could be easily removed by thermal treatment, and the mass would decrease.

\subsubsection{Sorption isotherm for metaettringite}

To evaluate the boron removal performance of metaettringite, the apparent sorption isotherm was measured by changing the initial boron concentration (Fig. 6). It is important to mention that the enhanced boron removal by metaettringite arose from the kinetic effect (not an equilibrium shift). The amount of boron contained in the ettringite structure, which is relevant because metaettringite forms ettringite as boron is removed, increased with increasing residual boron concentration, and the highest observed boron uptake by metaettringite was $15.1 \mathrm{mg}$ of boron per gram of metaettringite (mg-B/g-metaettringite) with a residual boron concentration of $363 \mathrm{mg}-\mathrm{B} / \mathrm{L}$ in solution. Table 3 compares the boron removal capacity of metaettringite with recent literature data for other solid materials. The observed maximum boron capacity for the prepared metaettringite was 
within the range of the reported values.

\subsubsection{Influence of $\mathbf{p H}$}

The pKa of boric acid in water at $25^{\circ} \mathrm{C}$ is $9.24^{21)}$. Thus, the $\mathrm{B}(\mathrm{OH})_{4}{ }^{-}$anion is predominant at $\mathrm{pH}$ values $>9.24$, while the uncharged $\mathrm{B}(\mathrm{OH})_{3}$ species is predominant at $\mathrm{pH}$ values $<9.24$. Conventional boron removal methods usually target $\mathrm{B}(\mathrm{OH})_{4}{ }^{-}$for removal. Thus, a high $\mathrm{pH}$ is required to remove boron. Figure 7 shows the boron removal performance of metaettringite with different initial solution $\mathrm{pH}$ values. Figure 8 shows changes in the solution $\mathrm{pH}$ with time during the experiment. The initial boron removal rate appeared to increase slightly with increasing initial solution $\mathrm{pH}$, whereas the residual boron concentrations were almost the same. However, the solution $\mathrm{pH}$ immediately increased to about 10 after addition of metaettringite (Fig. 8). Thus, it was difficult to examine the influence of the initial solution $\mathrm{pH}$ on boron removal by metaettringite. However, in practice, the initial solution $\mathrm{pH}$ did not strongly affect the overall boron removal performance of metaettringite. The $\mathrm{pH}$ increase was caused by partial dissolution of ettringite. However, the boron con-

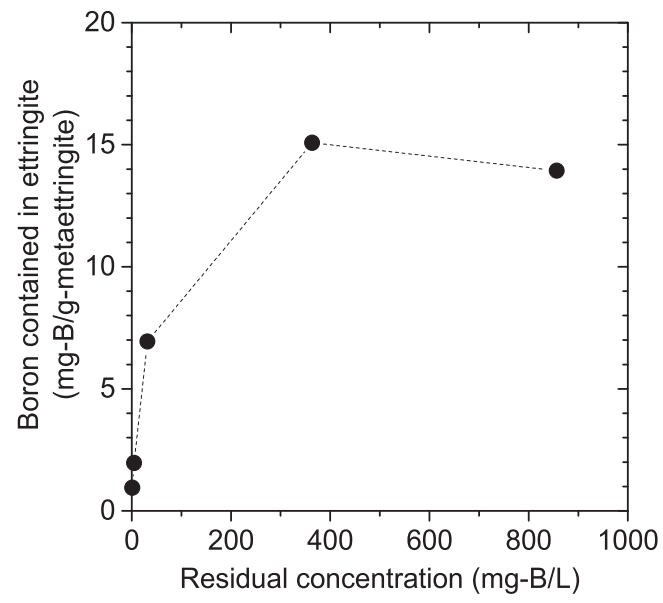

Fig. 6 Sorption isotherm of boron on metaettringite. Initial boron concentration $10-1000 \mathrm{mg}-\mathrm{B} / \mathrm{L}$, mass concentration of adsorbent $10 \mathrm{~g} / \mathrm{L}$, initial $\mathrm{pH} 11$, solution temperature $23^{\circ} \mathrm{C}$, particle size $53-106 \mu \mathrm{m}$, and removal time $2 \mathrm{~h}$

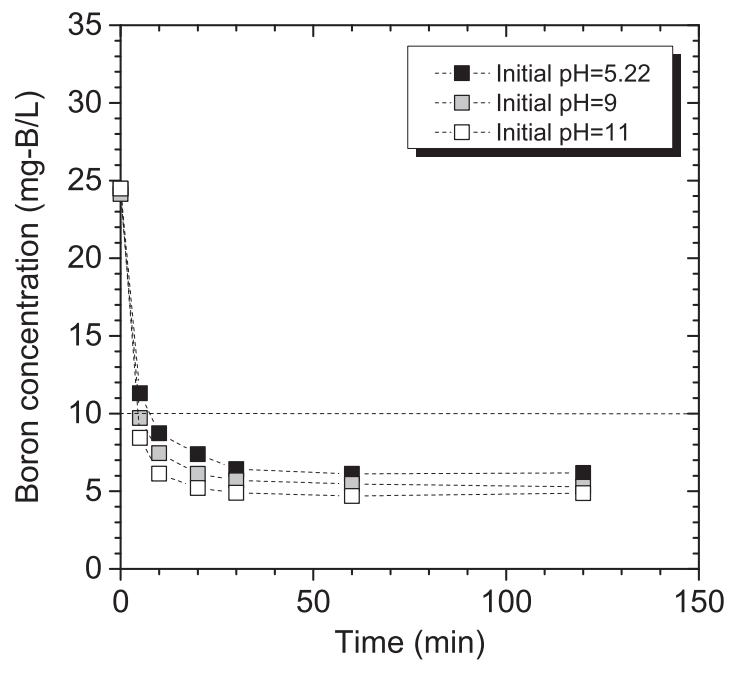

Fig. 7 The boron removal performance of metaettringite with different initial solution $\mathrm{pH}$ values. Initial boron concentration $25 \mathrm{mg}-\mathrm{B} / \mathrm{L}$, mass concentration of adsorbent $10 \mathrm{~g} / \mathrm{L}$, solution temperature $23^{\circ} \mathrm{C}$, and particle size 53-106 $\mu \mathrm{m}$.

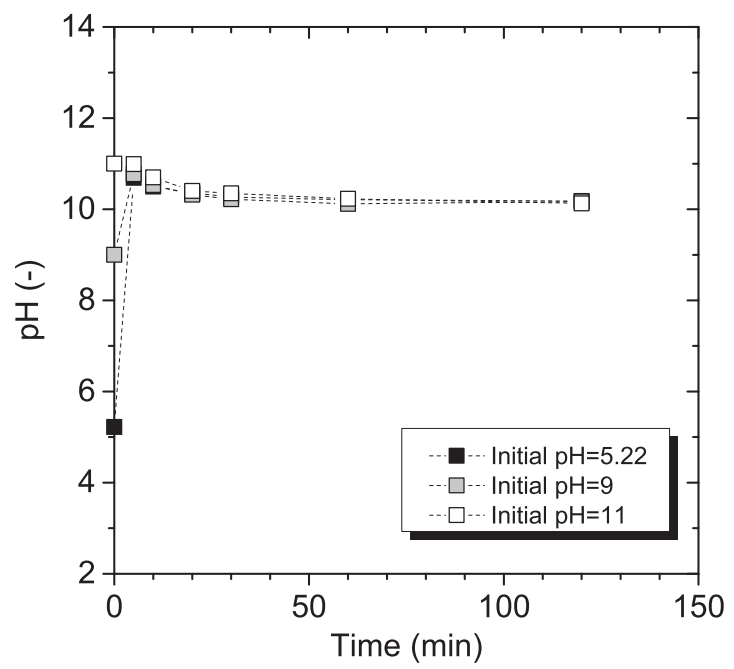

Fig. 8 Changes in the solution $\mathrm{pH}$ with time. Initial boron concentration $25 \mathrm{mg}-\mathrm{B} / \mathrm{L}$, mass concentration of adsorbent $10 \mathrm{~g} / \mathrm{L}$, solution temperature $23^{\circ} \mathrm{C}$, and particle size $53-106 \mu \mathrm{m}$.

Table 3 Comparison of the boron removal capacity of metaettringite with recent literature data for other solid materials.

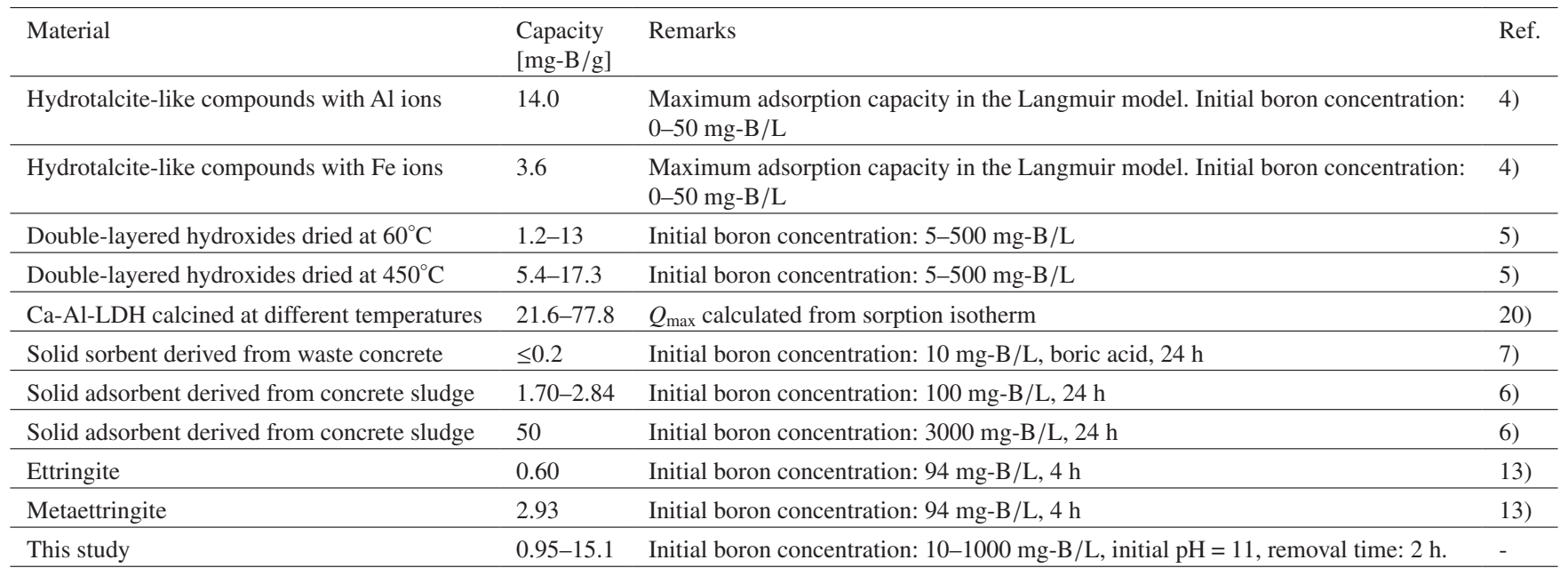


centration time courses were almost the same for all initial $\mathrm{pH}$ conditions, which indicated that the proportion of ettringite that dissolved was negligible. The observed difference in initial solution $\mathrm{pH}$ would reflect the initial concentration of $\mathrm{B}(\mathrm{OH})_{4}{ }^{-}$in the solution. It can be considered that the $\mathrm{B}(\mathrm{OH})_{3}$ present at $\mathrm{pH}<9.24$ was first converted to $\mathrm{B}(\mathrm{OH})_{4}{ }^{-}$as a result of the $\mathrm{pH}$ increase, and then recovered in the ettringite structure.

\subsubsection{Influence of particle size}

Both ettringite and metaettringite have high hydrophilicity, and both consist of fine needle-shaped primary particles. Enhancing the filterability and sedimentation properties is of great practical importance. Using coarse particles is one option to achieve this. Figure 9 shows the influence of particle size on the boron removal performances of ettringite and metaettringite. When large particles $(250-500 \mu \mathrm{m})$ were used for boron removal, the boron removal performance was slightly less than that obtained with small particles. The initial boron removal rate was not proportional to the surface area calculated assuming the particles were spherical. This is reasonable because ettringite and metaettringite are both agglomerated structures of small needle-shaped primary particles. The residual boron concentrations with metaettringite were still lower than the Japanese effluent standard ${ }^{22)}$. We also confirmed that the filterability of coarse particles was better than that of fine particles after boron uptake (data not shown).

\subsubsection{Influence of solution temperature}

Figure 10 shows the influence of solution temperature on the boron removal performance of ettringite and metaettringite. Figure 11 shows the time course for changes in the solution $\mathrm{pH}$ under different temperature conditions. The solution temperature did not significantly affect boron removal by ettringite in the temperature range from 10 to $50^{\circ} \mathrm{C}$. By contrast, the boron removal performance of metaettringite decreased with increasing temperature, and at temperatures above $50^{\circ} \mathrm{C}$, the residual boron concentration was higher than the Japanese standard. One reason for the lower boron removal performance by metaettringite at higher tempera-

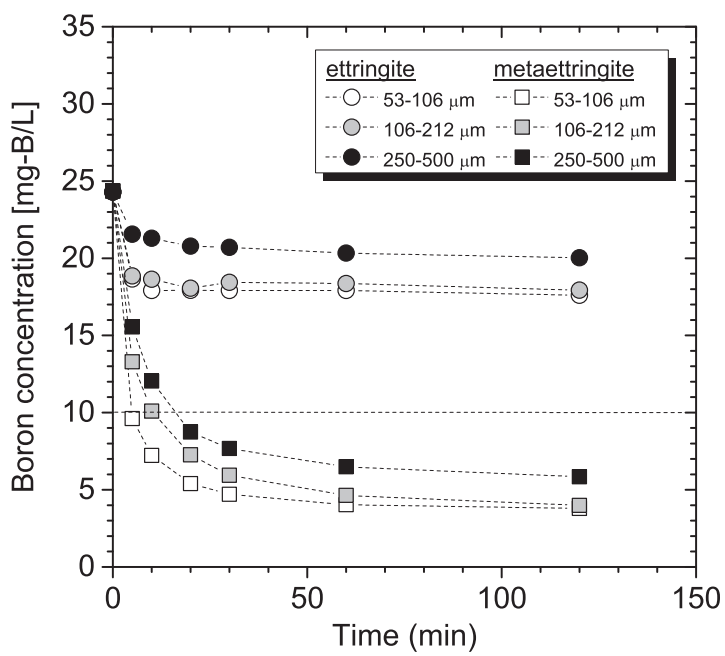

Fig. 9 Influence of particle size on the boron removal performance of ettringite and metaettringite. Initial boron concentration $25 \mathrm{mg}-\mathrm{B} / \mathrm{L}$,

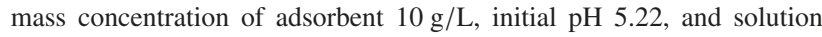
temperature $23^{\circ} \mathrm{C}$. tures compared with lower temperatures may be differences in the proportion of $\mathrm{B}(\mathrm{OH})_{4}{ }^{-}$in solution. As mentioned before, the $\mathrm{pKa}$ of boric acid in water at $25^{\circ} \mathrm{C}$ is $9.24^{21)}$, and the $\mathrm{pKa}$ usually decreases with increasing temperature. In our experiments, the final solution $\mathrm{pH}$ values at $50^{\circ} \mathrm{C}$ and $70^{\circ} \mathrm{C}$ were about 9.9 and 9.5 , respectively. Thus, $\mathrm{B}(\mathrm{OH})_{4}{ }^{-}$is the dominant species in solution for all experimental conditions, and differences in the proportion of $\mathrm{B}(\mathrm{OH})_{4}{ }^{-}$are not the main reason for inhibition of boron removal. We think that the ion exchange of $\mathrm{SO}_{4}{ }^{2-}$ with $\mathrm{B}(\mathrm{OH})_{4}{ }^{-}$in the ettringite structure would likely be exothermic, and the boron removal performance would decrease with increases in the temperature. Therefore, decreasing the solution temperature would be an easy and effective countermeasure for the suppression of boron removal.

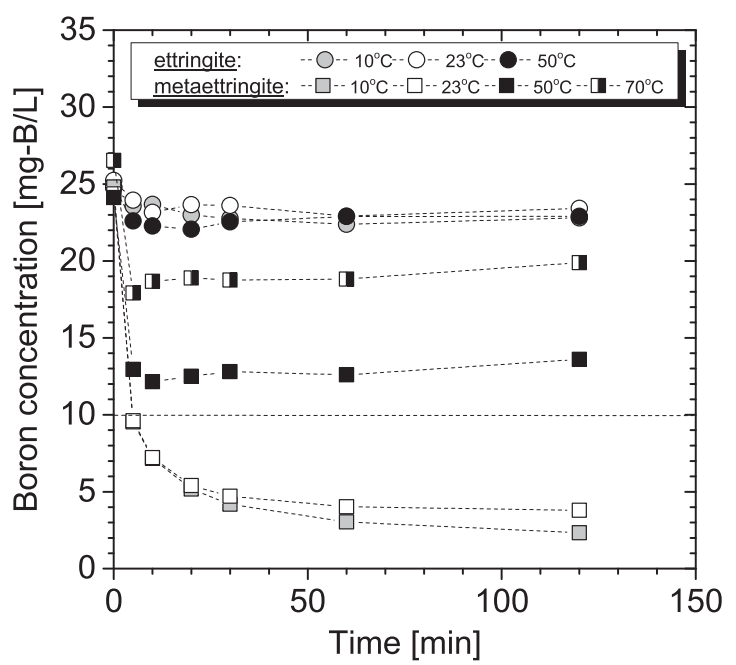

Fig. 10 Influence of solution temperature on the boron removal performance of ettringite and metaettringite. Initial boron concentration $25 \mathrm{mg}-\mathrm{B} / \mathrm{L}$, mass concentration of adsorbent $10 \mathrm{~g} / \mathrm{L}$, initial $\mathrm{pH} \mathrm{5.22,}$ and particle size $53-106 \mu \mathrm{m}$.

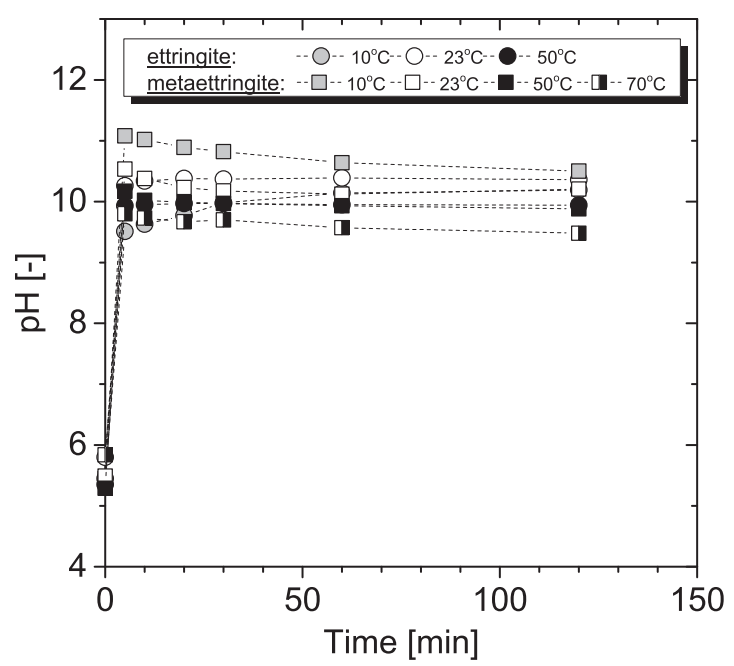

Fig. 11 Time course of changes in the solution $\mathrm{pH}$ under different temperature conditions. The initial boron concentration was $25 \mathrm{mg}-\mathrm{B} / \mathrm{L}$, the mass concentration of the adsorbent was $10 \mathrm{~g} / \mathrm{L}$, and the particle size was 53-106 $\mu \mathrm{m}$. 


\section{Conclusions}

Metaettringite powder was prepared, and its performance for the removal of boron from a low concentration solution ( $25 \mathrm{mg}-\mathrm{B} / \mathrm{L})$ was investigated. The target boron concentration and other parameters were determined taking into consideration the typical properties of mine wastewater in Japan. The influences of temperature during metaettringite preparation, initial solution $\mathrm{pH}$, particle size, and solution temperature on the boron removal performance were investigated. When the temperature during metaettringite preparation was $>65^{\circ} \mathrm{C}$, amorphous metaettringite formed, and this showed higher boron removal performance than ettringite. This conversion temperature is low enough that waste heat from industrial processes could be used for metaettringite preparation. The highest observed boron uptake by metaettringite was $15.1 \mathrm{mg}-\mathrm{B} / \mathrm{g}$-metaettringite with a residual boron concentration of $363 \mathrm{mg}-\mathrm{B} / \mathrm{L}$ in solution. Boron in solution could be effectively removed by metaettringite under a wide range of initial $\mathrm{pH}$ values (5.22 to 11 ). Residual boron concentrations lower than the Japanese effluent standard were attained even when using metaettringite with a large particle size. Strong suppression of boron removal by metaettringite was observed at a solution temperature above $50^{\circ} \mathrm{C}$. Therefore, decreasing the solution temperature would be an easy and effective countermeasure for suppression of boron removal. However, increasing the mass concentration of solid adsorbent in the boron solution resulted in a residual boron concentration lower than the Japanese standard.

For practical usage, synthesis of metaettringite from inexpensive aluminum sources, such as alumina $\left(\mathrm{Al}_{2} \mathrm{O}_{3}\right)$, would reduce the cost of materials for boron removal, although the boron removal performance would be lower than that obtained with pure metaettringite. The use of ettringite from waste materials ${ }^{6,7,23,24)}$ is also promising for boron removal from solution at low concentration.

\section{Acknowledgements}

This research was supported in part by the High Efficiency Rare Elements Extraction Technology Area, Tohoku Innovative Materials Technology Initiatives for Reconstruction, by the Arai Science and Technology
Foundation, and by the Steel Foundation for Environmental Protection Technology.

\section{REFERENCES}

1) Y. Xu and J.-Q. Jiang: Ind. Eng. Chem. Res. 47 (2008) 16-24.

2) N. Hilal, G.J. Kim and C. Somerfield: Desalination 273 (2011) 23-35.

3) B. Wang, X. Guo and P. Bai: Colloids Surf. A Physicochem. Eng. Asp. 444 (2014) 338-344.

4) O.P. Ferreira, S.G. de Moraes, N. Durán, L. Cornejo and O.L. Alves: Chemosphere 62 (2006) 80-88.

5) J.-Q. Jiang, Y. Xu, K. Quill, J. Simon and K. Shettle: Ind. Eng. Chem. Res. 46 (2007) 4577-4583.

6) T. Sasaki, Y. Sakai, T. Hongo, A. Iizuka and A. Yamasaki: Ind. Eng. Chem. Res. 51 (2012) 5813-5817.

7) A. Iizuka, M. Takahashi, T. Nakamura and A. Yamasaki: Ind. Eng. Chem. Res. 53 (2014) 4046-4051.

8) P. Kumarathasan, G. McCarthy, D.J. Hassett and D.F. PelughoeftHassett: Proc. MRS 178 (1989) 83.

9) H. Poellmann, S. Auer, H.-J. Kuzel and R. Wenda: Cement Concr. Res. 23 (1993) 422-430.

10) M. Zhang and E.J. Reardon: Environ. Sci. Technol. 37 (2003) 2947-2952.

11) Y. Hiraga and N. Shigemoto: J. Chem. Eng. of Jpn 43 (2010) $865-871$.

12) T. Tokumitsu, K. Sato, K. Toda and H. Morinaga: J. Ceram. Soc. Jpn. 114 (2006) 729-732.

13) T. Hongo, Y. Tsunashima, Y. Sakai, A. Iizuka and A. Yamasaki: Chem. Lett. 40 (2011) 1269-1271.

14) N.K. Skoblinskaya and K.G. Krasilnikov: Cement Concr. Res. 5 (1975) 381-393.

15) N.K. Skoblinskaya, K.G. Krasilnikov, L.V. Nikitina and V.P. Varlamov: Cement Concr. Res. 5 (1975) 419-431.

16) Q. Zhou and F.P. Glasser: Cement Concr. Res. 31 (2001) 1333-1339.

17) Q. Zhou, E.E. Lachowski and F.P. Glasser: Cement Concr. Res. 34 (2004) 703-710.

18) J. Pourchez, F. Valdivieso, P. Grosseau, R. Guyonnet and B. Guilhot: Cement Concr. Res. 36 (2006) 2054-2060.

19) A.E. Moore and H.F.W. Taylor: Acta Crystallogr. B 26 (1970) 386-393.

20) X. Qiu, K. Sasaki, Y. Takaki, T. Hirajima, K. Ideta and J. Miyawaki: J. Hazard. Mater. 287 (2015) 268-277.

21) Dean, J. A. (1987). Lange's Handbook of Chemistry, McGraw-Hill, New York, U.S.A.

22) Water Quality Pollution Control Act of Japan. (2011). Article 3, Environment Ministry of Japan, Tokyo, Japan.

23) Y. Tsunashima, A. Iizuka, J. Akimoto, T. Hongo and A. Yamasaki: Chem. Eng. J. 200-202 (2012) 338-343.

24) T. Hongo, Y. Tsunashima, A. Iizuka and A. Yamasaki: Int. J. Chem. Eng. Appl. 5 (2014) 298-302. 